BMJ Open Sport \& Exercise Medicine

\section{Danger zone assessment in small-sided recreational football: providing data for consideration in relation to COVID-19 transmission}

To cite: Randers MB, Knudsen NS, Thomasen MMD, et al. Danger zone assessment in small-sided recreational football: providing data for consideration in relation to COVID-19 transmission. BMJ Open Sport \& Exercise Medicine 2021;7:e000911. doi:10.1136/ bmjsem-2020-000911

Accepted 30 November 2020

Check for updates

(c) Author(s) (or their employer(s)) 2021. Re-use permitted under CC BY-NC. No commercial re-use. See rights and permissions. Published by BMJ.

For numbered affiliations see end of article.

Correspondence to Dr Morten B Randers; mranders@health.sdu.dk

\section{ABSTRACT}

During the COVID-19 pandemic, physical inactivity has increased, and a wide range of sporting activities locked down, with possible long-term implications for public health. Football is the most popular sport worldwide, and recreational football training leads to broad-spectrum health effects. Football is, however, deemed a contact sport with frequent close contact important to consider during COVID-19 pandemic.

Objectives This study investigated time spent with close contact (danger zone (DZ) within $1.5 \mathrm{~m}$ ), number of contacts and time per contact, and compared game formats in recreational small-sided football games for young and adult male football players.

Methods Movement analyses were performed on 10 $\mathrm{Hz}$ Global Positioning System (GPS) data collected during various small-sided football games prior to the COVID-19 outbreak.

Results Time spent in the DZ was 4.3-7.9 s/h per per cent infected players, corresponding to $34.3-114.8 \mathrm{~s} / \mathrm{h}$ if one player was infected. Number of contacts with one infected player was 23.5-87.7 per hour, with an average contact time of 1.1-1.4 s, and a total number of contacts of $311-691$ per hour with all players. $53 \%-65 \%$ of all contacts were shorter than $1 \mathrm{~s}$ and $77 \%-85 \%$ shorter than $2 \mathrm{~s}$. Trivial to small effects were found for number of participants and area per player, whereas standard of play and playing with/without boards had no effect.

Conclusion This study demonstrated that during small-sided football limited time is spent within DZ and that player contacts are brief. Recreational football may therefore more appropriately be deemed as sporting activity with brief, sporadic contact.

\section{INTRODUCTION}

The physical inactivity pandemic is a major challenge for global public health, with more than $30 \%$ of the world's population not meeting the minimum recommendations for physical activity defined by the WHO, ${ }^{1}$ which is causing approximately 3.2 million deaths every year. $^{2}$ The new COVID-19 pandemic

\section{What are the new findings?}

During recreational small-sided football games, limited time $(34-115 \mathrm{~s} / \mathrm{h})$ within a $1.5 \mathrm{~m}$ danger zone was observed, and $\sim 80 \%$ of all entries in the zone were shorter than $2 \mathrm{~s}$.

- Game format had no or very limited effect on time in the danger zone and on number and duration of contacts.

- Recreational small-sided football is better defined as sporting activity with brief, sporadic contact rather than a contact sport.

- Effects of game format variables were trivial to moderate, but $3 \mathrm{v} 3$ on a $31 \times 15.5 \mathrm{~m}$ pitch had the lowest time in danger zone (within $1.5 \mathrm{~m}$ ) and number of contacts per per cent infected player, and game format with few players also complies with the authorities' recommendation limiting the contact with a high number of people.

How might it impact on clinical practice in the future?

Authorities and governing bodies can use these scientific data to evaluate safe reopening of football for recreational players.

- As football is the most popular sport in the world, reopening of grassroots football, when safe, may have a major impact on public health around the world during and after COVID-19.

and the home confinement imposed by the authorities in many countries have led to a major changes in the physical activity pattern. ${ }^{3}$ Several studies have shown strong associations between sedentary behaviour and risk of mortality and morbidity, ${ }^{45}$ and physical activity is considered a cornerstone in the primary prevention of at least 26 chronic diseases. ${ }^{6}$ This highlights the importance of physical activity even under the 
special circumstances that the world is facing during the COVID-19 pandemic and the even greater importance for people to start being physically active again. ${ }^{3}$

Sport has been mentioned as a very important contributor to the health of nations and as an evidence-based therapy for various patient groups. ${ }^{6-8}$ The lockdown of sporting facilities and sports participation as a consequence of the COVID-19 pandemic may therefore accelerate the inactivity pandemic and have a number of negative health consequences that will only be recognised later. ${ }^{9}$ Subsequently, a rapid reopening of sporting facilities and sports communities, when safe, is highly important.

Football is the most popular sport, with more than 265 million footballers around the globe, the vast majority involved in amateur and recreational football. ${ }^{10}$ There is solid scientific evidence that recreational football is an effective broad-spectrum health-promoting activity across the lifespan, and an international platform, 'Football is Medicine', has been established. ${ }^{11-15}$ Football is, however, considered a contact sport, with frequent and close contacts between players during training and games, which is considered to put players at high risk of disease transmission. ${ }^{16}$ Authorities may therefore be reluctant to allow sports such as football, but the consideration that football is a contact sport with frequent and close contacts is not built on scientific evidence but on an assumption. This assumption can be evaluated using high time-resolution tracking data collected for all players during training and small-sided games (SSGs). ${ }^{17}$

COVID-19 is a viral infectious disease transmitted between humans by either direct contact or by respiratory droplets produced while breathing, coughing, sneezing and talking. ${ }^{9}$ Larger respiratory droplets $(>5 \mu \mathrm{m})$ fall rapidly to the ground within $1 \mathrm{~m}$, whereas smaller droplets can remain in the air for a longer period and distance depending on airflow, temperature and humidity. ${ }^{18}$ Authorities have therefore recommended social distancing of $1-2 \mathrm{~m}$ between individuals to limit virus transmission. ${ }^{19}{ }^{20}$ Direct contact, for example, touching hands or contact with surfaces, for example, the ball can be limited by not allowing throw-ins or touching during play and celebration, whereas keeping $1-2 \mathrm{~m}$ distance during match play may be more problematic.

Thus, the aim of this study is to test the hypothesis that number of contacts and time spent within this 'danger zone' (DZ) during recreational SSG is limited. As various game formats are used in recreational football training depending on the number of participants, available facilities and pitch sizes, ${ }^{21-24}$ different game formats are investigated and compared.

\section{METHODS \\ Design}

Positional data were retrieved from various recreational SSGs that took place before the COVID-19 lockdown (table 1). Positional data were collected using GPS units (MinimaxX S4, Catapult Innovations, Canberra, Australia) sampling at $10 \mathrm{~Hz}$ on all participants in various SSGs using different game formatting. Data were retrieved from various groups of recreationally trained adult men aged $18-43$ years and $\mathrm{U} 10$ boys aged $8-9$ years playing SSGs, as described in table 1.

\section{DZ calculation}

$\mathrm{X}$ and $\mathrm{Y}$ coordinates from the tracking data were retrieved, and data were filtered using a Butterworth fifthorder low-pass filter with a cut-off frequency of $0.08 \mathrm{~Hz}$ using a built-in MatLab function (The MathWorks, Inc, New York, USA). To evaluate the risk of being infected, a DZ was constructed as a circle with a radius of $1.5 \mathrm{~m}$ around each player's position. In addition to the circular zone, a tail followed each player as an area of the player's position up to $6 \mathrm{~s}$ ago. ${ }^{25}$ The tail that follows a player is modelling the decline in the amount of virus that stay airborne. Gravity pulls the droplets towards the ground,

Table 1 Game ID and game format characteristics for the included game formats

\begin{tabular}{|c|c|c|c|c|c|c|}
\hline Game ID & $\begin{array}{l}\text { Player } \\
\text { format }\end{array}$ & $\begin{array}{l}\text { Age (year) } \\
(\text { mean } \pm S D)\end{array}$ & $\begin{array}{l}\text { Pitch size } \\
(L \times W)\end{array}$ & $\begin{array}{l}\text { Area per player } \\
\left(\mathrm{m}^{2}\right)\end{array}$ & $\begin{array}{l}\text { Playing time } \\
\text { (min) }\end{array}$ & $\begin{array}{l}\text { Number of } \\
\text { comparisons }\end{array}$ \\
\hline $3 \vee 3$ WOB & $3 v 3$ & $28.4 \pm 4.2$ & $20 \times 13 m$ & 43 & $4 \times 12$ & 120 \\
\hline $3 \mathrm{v} 3 \mathrm{WB}$ & $3 \vee 3$ & $28.4 \pm 4.2$ & $20 \times 13 \mathrm{~m}$ & 43 & $4 \times 12$ & 120 \\
\hline $3 v 380$ & $3 v 3$ & $32.9 \pm 6.3$ & $31 \times 15.5 \mathrm{~m}$ & 80 & $4 \times 12$ & 120 \\
\hline $3 v 340 \times 20$ & $3 v 3$ & $32.6 \pm 6.6$ & $40 \times 20 m$ & 133 & $4 \times 12$ & 120 \\
\hline $5 v 540 \times 20$ & $5 \mathrm{v} 5$ & $32.8 \pm 6.5$ & $40 \times 20 m$ & 80 & $4 \times 12$ & 360 \\
\hline $7 v 740 \times 20$ & $7 \vee 7$ & $32.6 \pm 6.7$ & $40 \times 20 \mathrm{~m}$ & 57 & $4 \times 12$ & 702 \\
\hline $7 v 780$ & $7 v 7$ & $33.1 \pm 6.5$ & $47 \times 23.5 \mathrm{~m}$ & 80 & $4 \times 12$ & 728 \\
\hline $5 v 580$ & $5 v 5$ & $20.1 \pm 1.1$ & $40 \times 20 m$ & 80 & $2 \times 20$ & 540 \\
\hline $5 v 560$ & $5 v 5$ & $20.1 \pm 1.1$ & $35 \times 17 \mathrm{~m}$ & 60 & $2 \times 20$ & 180 \\
\hline $5 v 5 B$ & $5 v 5$ & $8-9$ & $30 \times 40 m$ & 120 & $1 \times 20$ & 540 \\
\hline $8 v 8 \mathrm{~B}$ & $8 v 8$ & $8-9$ & $52.5 \times 68 \mathrm{~m}$ & 223 & $1 \times 20$ & 960 \\
\hline
\end{tabular}

Game ID refers to player format and pitch size, area per player, with boards (WB) or without boards (WOB). 


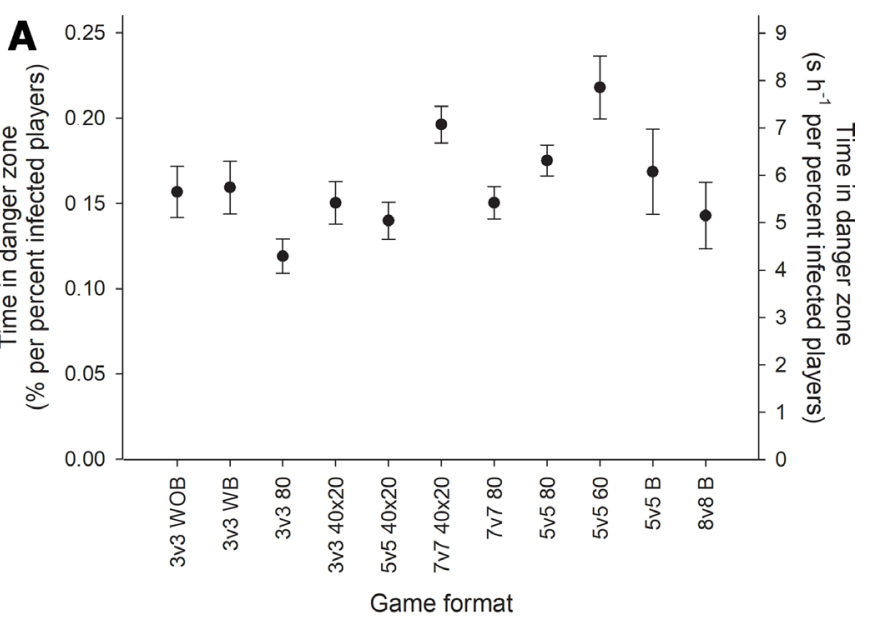

B

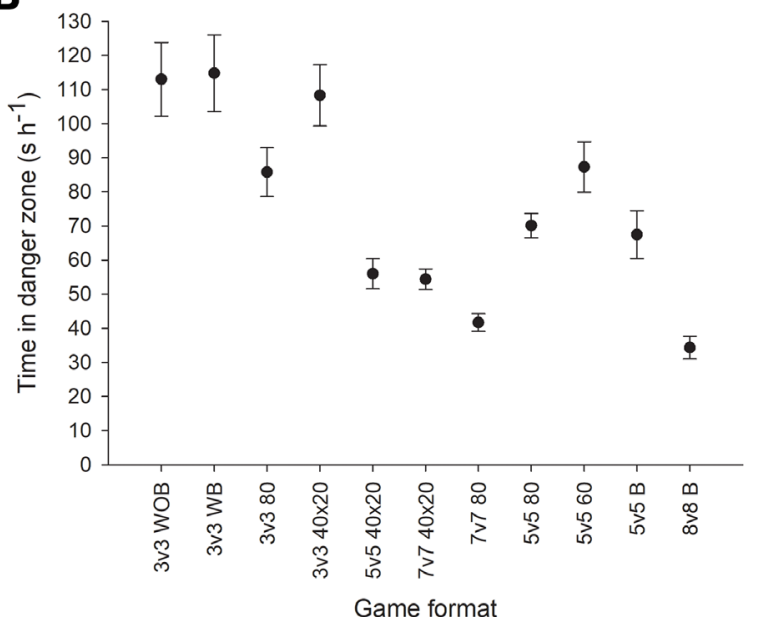

Figure 1 Time in danger zone (A) as \% per percent infected players and as $\mathrm{s} / \mathrm{h}$ per per cent infected players and $(\mathrm{B})$ as $\mathrm{s} / \mathrm{h}$ if one player is infected for various game formats. Data are presented as means $\pm 95 \%$ Cls.

and air resistance opposes this motion. This is modelled as an exponential decline in exposure score, and our function is based on the studies by Wells $(1934)^{26}$ and Wang et al $(2020)^{27}$. The danger value of this tail exponentially declines with a half-life of $2 \mathrm{~s}$. Thus, being within the area of $1.5 \mathrm{~m}$ from the other player returns a danger score of 1 , while being in the area where the other player was 2 and $4 \mathrm{~s}$ ago equates to danger scores of 0.5 and 0.25 , respectively.

If a player is within multiple zones at the same time, the score is determined as the maximal score of the zones. Accordingly, the maximal danger score at any time and position is 1 . An exposure score is calculated based on the sum of all danger scores divided by the sample frequency $(10 \mathrm{~Hz})$, which is then translated to how much time a player spent in $\mathrm{DZ}$ throughout the game. The calculations were performed with one infected player in each game and repeated until all participants had acted as the infected player, as previously described. ${ }^{25}$ Moreover, number of contacts was evaluated as the number of times a player entered in DZ, and the time of each entry was noted.
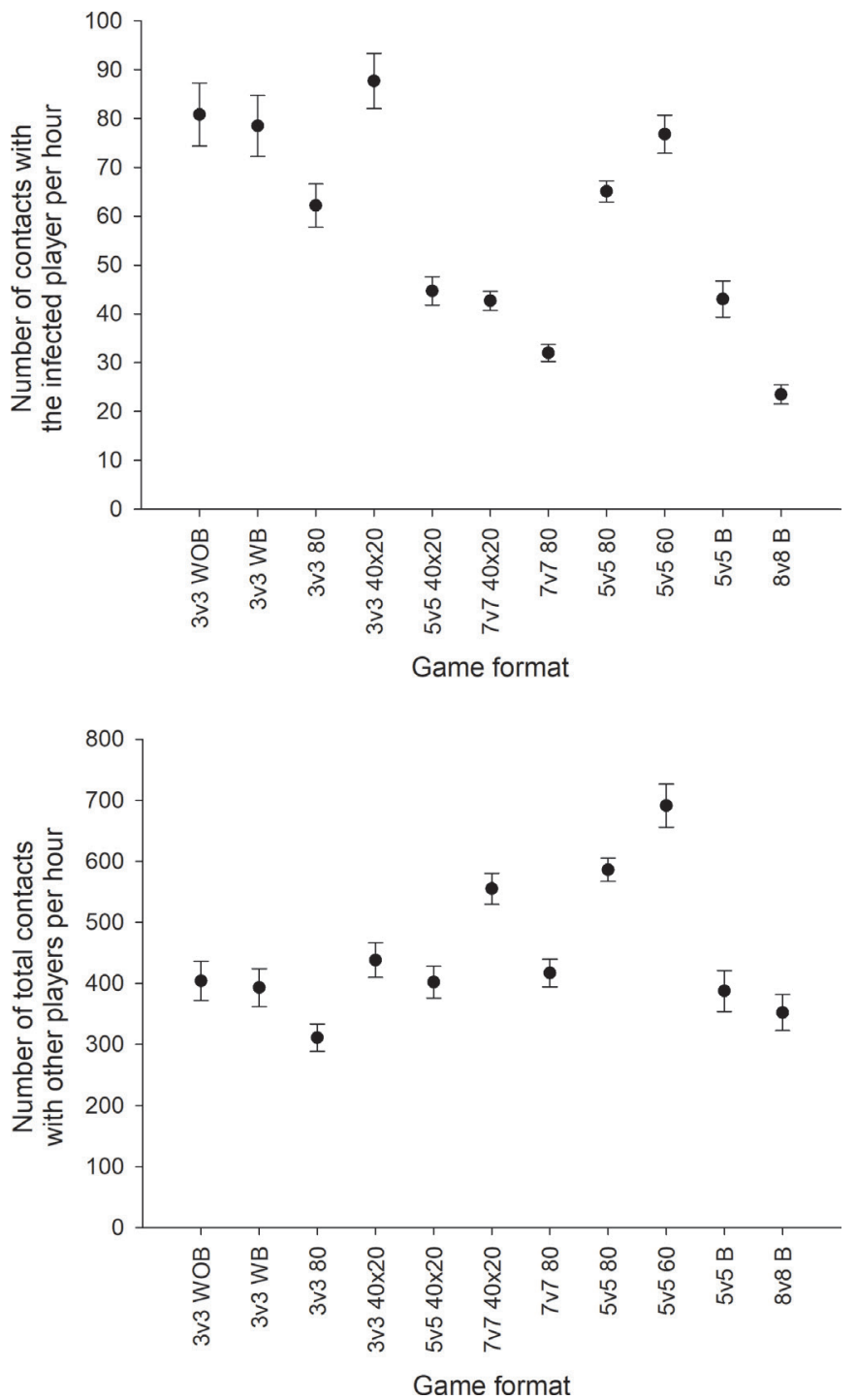

Figure 2 Number of contacts with the infected player assuming one player is infected $(A)$ and total number of contacts with other players for various game formats $(B)$. Data are presented as means $\pm 95 \%$ Cls.

\section{Statistical analysis}

Data are presented as means $( \pm 95 \%$ CIs $)$. Data are presented as per cent time in $\mathrm{DZ}$ and $\mathrm{s} / \mathrm{h}$ in order to compare SSGs of different duration. Moreover, to compare SSGs with different numbers of participants, data are presented as per per cent infected players (PPIP). If one player is infected, the likelihood of transmission is higher during $3 \mathrm{v} 3$ than $11 \mathrm{v} 11$ as a higher percentage is infected $(16.7 \%$ vs $4.5 \%)$. However, the likelihood that one player is infected is larger in a group of 22 than 6 random people, and therefore, to be able to compare the game format, data are presented as PPIP. If more players are infected, results can simply be multiplied with the percentage of infected players. Effect size (ES) was calculated using Cohen's $d$ and interpreted as suggested by Hopkins and colleagues. ${ }^{28}$ 


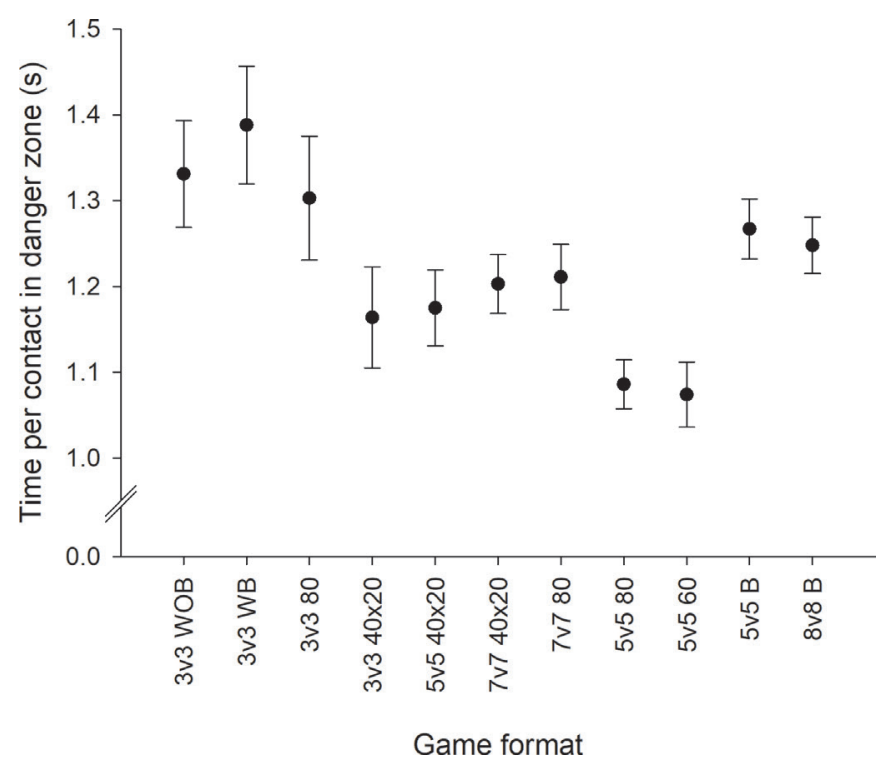

Figure 3 Time per contact in danger zone for various game formats. Data are presented as means $\pm 95 \%$ Cls.

\section{Patient and public involvement}

Patients and/or the public were not involved in the design, or conduct, or reporting, or dissemination plans of this research.

\section{RESULTS}

Per cent time spent in DZ PPIP ranged from 0.119 (0.109$0.129)$ to $0.218(0.200-0.237) \%$, which corresponds to 4.3 (3.9-4.7) to 7.9 (7.2-8.5) s/h PPIP (figure 1A). Assuming one participant in each game format is infected, time in DZ ranged from 34.3 (31.0-37.6) to 114.8 (103.7-126.0) $\mathrm{s} / \mathrm{h}$ (figure $1 \mathrm{~B}$ ).

Average number of contacts with the infected player, assuming one participant is infected, ranged from $23.5(21.5-25.5)$ to $87.7(82.0-93.3)$ contacts per hour (figure 2A), while the total number of contacts per player with all other players ranged from 311 (189-333) to 691 (656-726) contacts per hour (figure 2B).

Time per contact ranged from $1.1(1.0-1.1)$ to 1.4 (1.11.4) s (figure 3), with maximal observed contact time ranging from 11.0 to 61.0 s. $53 \%-65 \%$ and $77 \%-85 \%$ of all contacts were shorter than 1 and $2 \mathrm{~s}$, respectively. Of all contacts, $1.9 \%-3.5 \%$ and $0.1 \%-0.4 \%$ lasted more than 5 and 10 s, respectively (figure 4 ).

\section{Comparing number of players: fixed area per player $\left(80 \mathrm{~m}^{2}\right)$}

Players spent less time in DZ PPIP when playing 3v3 80 than $7 \mathrm{v} 780$, while $5 \mathrm{v} 540 \times 20$ did not differ from the two other formats (figure 1A), showing trivial to small effect sizes (ES=0.09-0.30). Number of contacts with the infected player (assuming one player was infected) was higher in 3v3 80 than in 5v5 20×40 and 7v7 80 (ES=0.66 and $\mathrm{ES}=1.25$, respectively) and higher in 5v5 20×40 than in 7v7 80 (ES=0.49; figure 2A). Conversely, adjusted for the number of participants, a lower number of contacts PPIP was observed in 3v3 80 than in 5v5 20×40 and 7v7 80 ( $\mathrm{ES}=0.46$ and $\mathrm{ES}=0.45$, respectively), with no difference

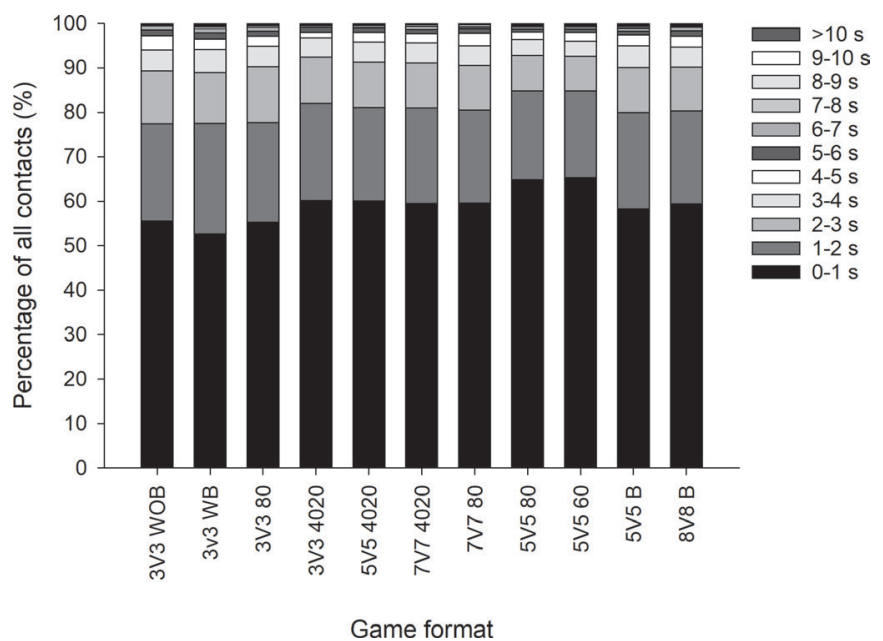

Figure 4 Distribution of time per contact for various game formats.

between $5 \mathrm{v} 520 \times 40$ and $7 \mathrm{v} 780$ (figure 2B). Total number of contacts was lower for 3v3 80 than for $5 \mathrm{v} 520 \times 40$ and $7 \mathrm{v} 780$ (ES=0.46 and $\mathrm{ES}=0.45$, respectively), while no difference was observed between 5v5 20×40 and 7v7 80 . Average time per contact was lower in $5 \mathrm{v} 540 \times 20$ than in 3v3 80 (ES=0.08), with no other differences between game formats (figure 3).

\section{Comparing area per player}

Players spent more time in DZ PPIP when playing in game formats with less area per player in $7 \mathrm{v} 7(7 \mathrm{v} 740 \times 20$ compared with 7v7 80; ES=0.32) and 5v5 (5v5 80 vs 5v5 60; $\mathrm{ES}=0.37$; figure $1 \mathrm{~A}, \mathrm{~B}$ ), while in $3 \mathrm{v} 3$ more time in DZ PPIP was found in $3 \mathrm{v} 3$ without boards (WOB) and $3 \mathrm{v} 340 \times 20$ than in 3v3 80 (figure $1 \mathrm{~A}, \mathrm{~B}$; $\mathrm{ES}=0.53$ and $\mathrm{ES}=0.49$, respectively). Number of contacts with the infected player was higher in game formats with less area per player in $7 \mathrm{v} 7$ ( $\mathrm{ES}=0.43$ ) and $5 \mathrm{v5}$ ( $\mathrm{ES}=0.45$; figure $2 \mathrm{~A}$ ) but not clear for $3 \mathrm{v} 3$, with higher number of contacts in 3v3 WOB and 3v3 $40 \times 20$ than in 3v3 80 ( $\mathrm{ES}=0.60$ and $\mathrm{ES}=0.90$, respectively). Time per contact did not differ for game formats in $7 \mathrm{v} 7$ and $5 \mathrm{v} 5$ but was lower in $3 \mathrm{v} 340 \times 20$ than in $3 \mathrm{v} 3 \mathrm{WOB}$ and 3v3 80 (figure 3; $\mathrm{ES}=0.12$ and $\mathrm{ES}=0.17$, respectively). In U10 boys, no differences were observed between $120 \mathrm{~m}^{2}$ and $223 \mathrm{~m}^{2}$ (5v5 B vs $8 v 8 \mathrm{~B}$ ) for time in DZ PPIP, number of contacts with the infected player PPIP or average time per contact.

\section{Comparing with boards (WB) or WOB}

No differences were observed in time in DZ PPIP, number of contacts with the infected player, total number of contacts or average time per contact in SSGs on very small pitches $\left(43 \mathrm{~m}^{2}\right.$ per player $)$ with or without boards (3v3 WB vs 3v3 WOB).

\section{DISCUSSION}

The main findings of the present study were that time within DZ was low, with 4-8s per hour PPIP. This corresponds to less than $2 \mathrm{~min}$ per hour, assuming one infected player, during 3v3 to $8 \mathrm{v} 8$ games. Moreover, assuming one 
infected player, the average number of contacts with the infected player was 23-88 per hour, with a total number of contacts with all other players of 311-691 per hour. Of these contacts, $53 \%-65 \%$ were shorter than $1 \mathrm{~s}$ and $77 \%-85 \%$ shorter than 2 s. Common SSG format variables such as number of players, area per player and with or without boards keeping the ball in play seem to have very little effect on time spent in DZ PPIP, number of contacts or average time per contact.

Although football is considered a contact sport with frequent and close contacts, ${ }^{16}$ the present study showed by detailed analysis of tracking data that time spent within DZ was surprisingly low, at 34-115 s per hour, assuming one participant was infected. Obviously, SSGs with the fewest players are those with most time spent in DZ if the assumption is that on player is infected. In contrast, the likelihood that one player is infected is lower when few players gather for a football game compared with larger number of players. Data were therefore presented as PPIP in order to calculate a risk score based on per cent infected in each population and to make a direct comparison between game formats with various numbers of players.

A contact with the infected player, assuming one player was infected, occurred once every $0.7-2.6 \mathrm{~min}$ depending on game format. Each of these contacts was, however, rather short, with around $80 \%$ shorter than $2 \mathrm{~s}$ and less than $0.5 \%$ longer than $10 \mathrm{~s}$. It should be noted that the calculated number of contacts is the number of entries into the $\mathrm{DZ}$ and not direct contact, which is also considered a critical pathway of transmission of virus. ${ }^{29}$ In this study, direct contacts were not evaluated, but a few video analyses have demonstrated that the scarce direct contacts were primarily shoulder to shoulder or contacts with the feet/legs (data not shown).

Various gaps for social distancing have been proposed by authorities; the WHO suggests $1 \mathrm{~m}$, the Centers for Disease Control and Prevention (USA) $1.8 \mathrm{~m}$ and the National Health Service (UK) $2 \mathrm{~m}$. These gaps are based on the distances that droplets from sneezing, coughing or talking travel before gravity pulls them to the ground in normal settings, whereas distances may be slightly longer in special environments. ${ }^{30}$ In the present study, it was decided to use $1.5 \mathrm{~m}$ as the radius for the distance zone and, in addition, to consider the tail from the player's run. A study by Blocken and colleagues ${ }^{31}$ used computer simulation of aerodynamics of droplet movements in a wind tunnel to show that exposure is up to $5 \mathrm{~m}$ when walking at $4 \mathrm{~km} / \mathrm{h}$ and $10 \mathrm{~m}$ when running $14.4 \mathrm{~km} / \mathrm{h}$ in the slipstream of an infected person, but exposure dropped markedly when running side by side or staggered. Unlike track or trail running, running in the slipstream for several seconds is unusable in football. Moreover, previous studies have demonstrated that, for adults, speed exceeds $13 \mathrm{~km} / \mathrm{h} \mathrm{30-70} \mathrm{times} \mathrm{during} \mathrm{a}$ training session, with each high-speed run lasting only a few seconds. ${ }^{21-24}$ In U10 players, less than $10 \%$ of the total time was spent at speeds above $12 \mathrm{~km} / \mathrm{h}{ }^{32}$ Thus, the increased exposure due to slipstream dynamics for a footballer may be negligible.

Across SSG formats, intensity is high, with 10\%-40\% of the total time spent with heart rate above $90 \%$ HRmax $^{22-2433}$ and a significant distance at high speed. Breathing is therefore considerably elevated during SSGs, slightly increasing the risk of inhaling virus via droplets. ${ }^{34}$ Regular moderate-intensity training, however, is generally associated with decreased risk of respiratory tract infections, whereas a low physical activity level increases this hazard. ${ }^{35}$ Thus, the overall benefits of SSGs may counteract this increased risk from excessive breathing.

\section{Effects of game format}

Different SSG formats were analysed to investigate the effect of number of players, relative pitch area and playing with or without boards.

Number of players had very little effect on time in DZ and number of contacts. Fewer players led to more time in $\mathrm{DZ}$ and more contacts but, when adjusting for the higher risk of one infected player in a larger rather than a smaller group, 3v3 had the most favourable values. Effect sizes were, however, trivial to small.

The less available area per player, the higher the density, so it is expected that time spent in DZ and number of contacts will be elevated when the area per player drops. This was also confirmed in the $5 \mathrm{v} 5$ and $7 \mathrm{v} 7$ game formats, while in $3 \mathrm{v} 3$, the highest time in $\mathrm{DZ}$ and highest number of contacts were observed during 3v3 with $43 \mathrm{~m}^{2}$ and $133 \mathrm{~m}^{2}$ compared with $80 \mathrm{~m}^{2}$. It is possible that more man-marking is practised when pitch size increases, resulting in a more run-based style of play. It has previously been shown that $3 \mathrm{v} 3$ on a $40 \times 20 \mathrm{~m}$ pitch $\left(133 \mathrm{~m}^{2}\right)$ is more demanding than $5 \mathrm{v} 5$ or $7 \mathrm{v} 7$ on a similar pitch $(40 \times 20 \mathrm{~m}) \cdot{ }^{23}$ The effects were small to moderate in adults, while no effects of area per player were observed in U10 boys.

In many larger cities, there is limited availability of football pitches or grass areas in parks, so football in urban areas is often played as very small-sided games on pitches surrounded by boards. This keeps the ball in play, but it also limits the players' movement area $^{22}$; however, no effect of boards was observed in time within DZ and number of contacts with the infected player.

All the analysed SSGs are typical game formats and have previously been shown to elicit high heart rates and impact on the body, ${ }^{21-24} 3233$ which is expected to lead to several beneficial health parameters if conducted regularly over a 12 -week period. ${ }^{111215}$

\section{Limitations}

The current study only investigated recreational adults during SSGs and not 11v11. Based on the current study, transmission risk in competitive grassroots football cannot be evaluated. Movement patterns in professional players in the Danish Premier League have been analysed using similar methodology to that applied in the present study, demonstrating that the average time in DZ was 
$87.8 \mathrm{~s}$ for $90 \mathrm{~min}^{25}$ Adjusted for the number of players on the pitch, time in DZ was approximately $37 \%-150 \%$ higher during professional 11v11 matches than observed in the current study, partly due to a $\sim 3$ times higher time per contact. ${ }^{25}$ Thus, even though the current study cannot deem competitive grassroots 11v11 safe, time in $\mathrm{DZ}$ is likely to be comparable with data presented for professional or recreational SSGs.

The data were collected prior to the COVID-19 outbreak, thus not reflecting the new reality. However, these tracking data reflect normal player behaviour before any engagement with official guidelines, meaning that the players came together to celebrate goals and in general may be expected to have had more close contacts than under COVID-19. Only game periods were analysed, and it is very likely that players gather together during breaks. It is, nevertheless, easier to follow official guidelines during breaks than during match play, when players may be expected to act more intuitively and based on the game routines. It should be emphasised, however, that activities around the sporting activity usually include close and prolonged social contact, such as transportation, changing room activities and meetings, which were not evaluated in this study.

\section{CONCLUSION}

This study presented data on time spent within a $1.5 \mathrm{~m}$ $\mathrm{DZ}$ and on number and duration of contacts in relation to the risk of COVID-19 transmission in recreational football. The study revealed that only a short time is spent within the DZ and that the contacts are brief irrespective of game format. The present results suggest that recreational small-sided football is better defined as sporting activity with brief, sporadic contact rather than a contact sport.

\section{Author affiliations \\ ${ }^{1}$ Department of Sports Science and Clinichal Biomechanics, University of Southern Denmark Faculty of Health Sciences, Odense, Denmark \\ ${ }^{2}$ School of Sport Sciences, UiT Arctic University of Norway, Tromso, Norway ${ }^{3}$ Section for Sport Science, Department of Public Health, Aarhus Universitet, Aarhus, Denmark \\ ${ }^{4}$ Faculty of Health Sciences, University of Southern Denmark, Odense, Denmark ${ }^{5}$ Centre of Health Science, Faculty of Health, University of the Faroe Islands, Torshavn, Faroe Islands \\ ${ }^{6}$ Faculty of Sport and Physical Education, University of Nis, Nis, Serbia \\ ${ }^{7}$ Science and Research Centre Koper, Institute for Kinesiology Research, Koper, Slovenia \\ ${ }^{8}$ Faculty of Sports Studies, Incubator of Kinanthropological Research, Masaryk University, Brno, Czech Republic}

Twitter Morten B Randers @RandersMB and Zoran Milanovic @zoooro_85

Acknowledgements The authors would like to thank all the participants in the small-sided games.

Contributors MBR, MM, PK and TBA contributed to the ideation of the study. MBR JP, MNL and ZM collected the data. MBR, NSK and MMDT prepared and processed the data. MBR drafted the manuscript. All authors provided intellectual contribution to the writing of the manuscript and have accepted the final version.

Funding Nordea-fonden, Denmark, supported the original studies for which the tracking data were collected.
Competing interests PK is employed by the Danish Football Association as fitness coach for the women's national team. MM is fitness coach for the Faroese men's national football team.

Patient consent for publication Not required.

Provenance and peer review Not commissioned; externally peer reviewed.

Data availability statement Data are available on reasonable request. Please contact the corresponding author for access to tracking data.

Open access This is an open access article distributed in accordance with the Creative Commons Attribution Non Commercial (CC BY-NC 4.0) license, which permits others to distribute, remix, adapt, build upon this work non-commercially, and license their derivative works on different terms, provided the original work is properly cited, appropriate credit is given, any changes made indicated, and the use is non-commercial. See: http://creativecommons.org/licenses/by-nc/4.0/.

\section{ORCID iDs}

Morten B Randers http://orcid.org/0000-0002-0192-8981

Manuel Mounir Demetry Thomasen http://orcid.org/0000-0002-9379-4617

Jeppe Panduro http://orcid.org/0000-0002-8887-8875

Malte Nejst Larsen http://orcid.org/0000-0002-2600-7126

Magni Mohr http://orcid.org/0000-0002-1749-8533

Zoran Milanovic http://orcid.org/0000-0002-3224-0506

Peter Krustrup http://orcid.org/0000-0002-0192-8981

Thomas Bull Andersen http://orcid.org/0000-0003-0813-6896

\section{REFERENCES}

1 Kohl HW, Craig CL, Lambert EV, et al. The pandemic of physical inactivity: global action for public health. Lancet 2012;380:294-305

2 Hallal PC, Andersen LB, Bull FC, et al. Global physical activity levels: surveillance progress, pitfalls, and prospects. Lancet 2012;380:247-57.

3 Hall G, Laddu DR, Phillips SA, et al. A tale of two pandemics: how will COVID-19 and global trends in physical inactivity and sedentary behavior affect one another? Prog Cardiovasc Dis 2020. doi:10.1016/j.pcad.2020.04.005. [Epub ahead of print: 08 Apr 2020].

4 Wahid A, Manek N, Nichols M, et al. Quantifying the association between physical activity and cardiovascular disease and diabetes: a systematic review and meta-analysis. J Am Heart Assoc 2016;5:e002495

5 Engeseth K, Prestgaard EE, Mariampillai JE, et al. Physical fitness is a modifiable predictor of early cardiovascular death: a 35-year follow-up study of 2014 healthy middle-aged men. Eur J Prev Cardiol 2018;25:1655-63.

6 Pedersen BK, Saltin B. Exercise as medicine - evidence for prescribing exercise as therapy in 26 different chronic diseases. Scand J Med Sci Sports 2015;25(Suppl 3):1-72.

7 Khan KM, Thompson AM, Blair SN, et al. Sport and exercise as contributors to the health of nations. Lancet 2012;380:59-64.

8 Andersen LB, Schnohr P, Schroll M, et al. All-Cause mortality associated with physical activity during leisure time, work, sports, and cycling to work. Arch Intern Med 2000;160:1621-8.

9 Lippi G, Henry BM, Bovo C, et al. Health risks and potential remedies during prolonged lockdowns for coronavirus disease 2019 (COVID-19). Diagnosis 2020;7:85-90.

10 FIFA. FIFA big count 2006: 270 million people active in football. FIFA Comunication Division 2007.

11 Krustrup P, Helge EW, Hansen PR, et al. Effects of recreational football on women's fitness and health: adaptations and mechanisms. Eur J Appl Physiol 2018;118:11-32.

12 Milanović Z, Pantelić S, Čović N, et al. Broad-Spectrum physical fitness benefits of recreational football: a systematic review and meta-analysis. Br J Sports Med 2019;53:926-39.

13 Oja P, Titze S, Kokko S, et al. Health benefits of different sport disciplines for adults: systematic review of observational and intervention studies with meta-analysis. $\mathrm{Br} J$ Sports Med 2015;49:434-40.

14 Krustrup P, Williams CA, Mohr M, et al. The "Football is Medicine" platform-scientific evidence, large-scale implementation of evidence-based concepts and future perspectives. Scand J Med Sci Sports 2018;28(Suppl 1):3-7.

15 Krustrup P, Krustrup BR. Football is medicine: it is time for patients to play! Br J Sports Med 2018;52:1412-4.

16 Corsini A, Bisciotti GN, Eirale C, et al. Football cannot restart soon during the COVID-19 emergency! A critical perspective 
from the Italian experience and a call for action. $\mathrm{Br} J$ Sports Med 2020;54:1186-7.

17 Gonçalves B, Mendes R, Folgado H, et al. Can tracking data help in assessing interpersonal contact exposure in team sports during the COVID-19 pandemic? Sensors 2020;20. doi:10.3390/s20216163. [Epub ahead of print: 29 Oct 2020].

18 Chartier Y, Pessoa-Silva C. Natural ventilation for infection control in health-care settings. World Health Organization, 2009.

19 WHO. Coronavirus disease (COVID-19) advice for the public, 2020. Available: https://www.who.int/emergencies/diseases/novelcoronavirus-2019/advice-for-public2020 [Accessed 19 Jun 2020].

20 NHS. Social distancing: what you need to do, 2020. Available: https://www.nhs.uk/conditions/coronavirus-covid-19/socialdistancing/what-you-need-to-do/2020 [Accessed 19 Jun 2020].

21 Randers MB, Nielsen JJ, Bangsbo J, et al. Physiological response and activity profile in recreational small-sided football: no effect of the number of players. Scand J Med Sci Sports 2014;24(Suppl 1):130-7.

22 Randers MB, Brix J, Hagman M, et al. Effect of boards in SmallSided street soccer games on movement pattern and physiological response in recreationally active young men. $J$ Strength Cond Res 2020;34:3530-7.

23 Randers MB, Ørntoft C, Hagman M, et al. Movement pattern and physiological response in recreational small-sided football effect of number of players with a fixed pitch size. J Sports Sci 2018;36:1549-56.

24 Pantelić S, Rađa A, Erceg M, et al. Relative pitch area plays an important role in movement pattern and intensity in recreational male football. Biol Sport 2019;36:119-24.

25 Knudsen NS, Thomasen MMD, Andersen TB. Spread of virus during soccer matches. medRxiv 2020.
26 Wells WF. On air-borne infection: study II. droplets and droplet nuclei. American Journal of Epidemiology 1934;20:611-8.

27 Wang B, Wu H, Wan X-F. Transport and fate of human expiratory droplets-A modeling approach. Phys Fluids 2020;32:083307.

28 Hopkins WG, Marshall SW, Batterham AM, et al. Progressive statistics for studies in sports medicine and exercise science. Med Sci Sports Exerc 2009;41:3-13.

29 Moriyama M, Hugentobler WJ, Iwasaki A. Seasonality of respiratory viral infections. Annu Rev Virol 2020;7:83-101.

30 WHO. Modes of transmission of virus causing COVID-19: implications for IPC precaution recommendations: scientific brief, 27 March 2020. World Health Organization, 2020.

31 Blocken B, Malizia F, van Druenen T. Towards aerodynamically equivalent COVID-19 $1.5 \mathrm{~m}$ social distancing for walking and running, 2020. Available: http://wwwurbanphysicsnet/COVID19 Aero_Paperpdf [Accessed 19 Jun 2020].

32 Randers MB, Andersen TB, Rasmussen LS, et al. Effect of game format on heart rate, activity profile, and player involvement in elite and recreational youth players. Scand J Med Sci Sports 2014;24(Suppl 1):17-26.

33 Randers MB, Nybo L, Petersen J, et al. Activity profile and physiological response to football training for untrained males and females, elderly and youngsters: influence of the number of players. Scand J Med Sci Sports 2010;20(Suppl 1):14-23.

34 Toresdahl BG, Asif IM. Coronavirus disease 2019 (COVID-19): considerations for the competitive athlete. Los Angeles, CA: SAGE Publications, 2020

35 Nieman DC, Wentz LM. The compelling link between physical activity and the body's defense system. J Sport Health Sci 2019;8:201-17. 